Open Access

\title{
Partial genome sequence of the haloalkaliphilic soda lake bacterium Thioalkalivibrio thiocyanoxidans ARh $2^{\top}$
}

\author{
Tom Berben ${ }^{1}$, Dimitry Y. Sorokin ${ }^{2,3}$, Natalia Ivanova ${ }^{4}$, Amrita Pati ${ }^{4}$ Nikos Kyrpides ${ }^{4}$, Lynne A. Goodwin ${ }^{4}$, \\ Tanja Woyke ${ }^{4}$ and Gerard Muyzer ${ }^{1 *}$ (i)
}

\begin{abstract}
Thioalkalivibrio thiocyanoxidans strain ARh $2^{\top}$ is a sulfur-oxidizing bacterium isolated from haloalkaline soda lakes. It is a motile, Gram-negative member of the Gammaproteobacteria. Remarkable properties include the ability to grow on thiocyanate as the sole energy, sulfur and nitrogen source, and the capability of growth at salinities of up to 4.3 $\mathrm{M}$ total $\mathrm{Na}^{+}$. This draft genome sequence consists of 61 scaffolds comprising 2,765,337 bp, and contains 2616 protein-coding and 61 RNA-coding genes. This organism was sequenced as part of the Community Science Program of the DOE Joint Genome Institute.
\end{abstract}

Keywords: Haloalkaliphilic, Soda lakes, Sulfur-oxidizing bacteria, Thiocyanate

\section{Introduction}

Soda lakes are found in many arid zones across the world, such as the Kulunda Steppe in Russia, North-Eastern China, the Rift Valley in Africa, and in arid parts of North America, i.e. California and Nevada. The defining characteristics of these lakes are the abundance of carbonate/bicarbonate anions rather than chloride and their moderate to high salinities. This makes soda lakes a unique habitat with stable, alkaline $\mathrm{pH}$ values above nine and up to 11 [1]. Despite the high salinity and alkalinity, soda lakes harbor a rich microbial diversity that is responsible for highly active elemental cycles. Aside from the carbon cycle, the sulfur cycle is of great importance in these lakes [2], yet little is known about their precise biogeochemistry and dynamics [3]. A better understanding of these processes will lead to improved insights into the ecology and biogeochemical cycling in soda lakes. Additionally, sulfur-cycling extremophilic prokaryotes have important applications in bioremediation [4] and more detailed knowledge of their physiology may improve industrial waste processing. For these reasons, we have sequenced more than

\footnotetext{
* Correspondence: g.muijzer@uva.nl

'Microbial Systems Ecology, Institute of Biodiversity and Ecosystem Dynamics, University of Amsterdam, Amsterdam, The Netherlands Full list of author information is available at the end of the article
}

70 strains belonging to the genus Thioalkalivibrio, a dominant cultivated group of chemolithoautotrophic haloalkaliphilic sulfur-oxidizing bacteria in soda lakes worldwide. Here we present the partial genome sequence of Thioalkalivibrio thiocyanoxidans ARh $2^{\mathrm{T}}$.

\section{Organism information}

\section{Classification and features}

T. thiocyanoxidans ARh $2^{\mathrm{T}}$ forms motile vibrio-like cells of approximately $0.5-0.6$ by $0.8-1.4 \mu \mathrm{m}$ (basic properties are summarized in Table 1). The cells grown with thiocyanate as electron source have a remarkably extended periplasm (Fig. 1). It is a Gram-negative bacterium belonging to the Gammaproteobacteria (Fig. 2). The species description is based on four strains (ARh 2, ARh 3, ARh 4 and ARh 5) that were isolated from sediment samples of South-Western Siberian, Kenyan and Egyptian soda lakes. Strain ARh 2 is a type strain of the $T$. thiocyanoxidans species. As a chemolithoautotroph, ARh $2^{\mathrm{T}}$ derives energy from the oxidation of inorganic sulfur compounds, such as sulfide, thiosulfate, thiocyanate, elemental sulfur and polysulfides. The most interesting properties are its ability to grow on thiocyanate as the sole source of energy, sulfur and nitrogen and its ability to grow in saturated soda brines brines with thiosulfate as energy source [5]. 
Table 1 Classification and general features of Thioalkalivibrio thiocyanoxidans ARh $2^{\top}[12]$

\begin{tabular}{|c|c|c|c|}
\hline MIGS ID & Property & Term & $\begin{array}{l}\text { Evidence } \\
\text { code }^{a}\end{array}$ \\
\hline & \multirow[t]{8}{*}{ Classification } & Domain Bacteria & TAS [13] \\
\hline & & Phylum Proteobacteria & TAS $[14,15$ \\
\hline & & Class Gammaproteobacteria & $\operatorname{TAS}[15,16$ \\
\hline & & Order Chromatiales & $\operatorname{TAS}[15,17$ \\
\hline & & Family Ectothiorhodospiraceae & TAS [18] \\
\hline & & Genus Thioalkalivibrio & TAS [19] \\
\hline & & $\begin{array}{l}\text { Species Thioalkalivibrio } \\
\text { thiocyanoxidans }\end{array}$ & TAS [5] \\
\hline & & $\begin{array}{l}\text { Type strain: ARh } 2^{\top} \\
\text { (DSM 13532) }\end{array}$ & \\
\hline & Gram stain & Negative & $\operatorname{TAS}[5,19]$ \\
\hline & Cell shape & Vibrios & TAS [5] \\
\hline & Motility & Motile & TAS [5] \\
\hline & Sporulation & Non-sporulating & NAS \\
\hline & Temperature range & Mesophilic & TAS [5] \\
\hline & Optimum temperature & $35-37^{\circ} \mathrm{C}$ & TAS [5] \\
\hline & pH range; Optimum & $8.5-10.5$ & TAS [5] \\
\hline & Carbon source & Inorganic carbon & TAS [5] \\
\hline MIGS-6 & Habitat & Soda lakes & TAS [5] \\
\hline MIGS-6.3 & Salinity & $0.3-4.3 \mathrm{M} \mathrm{Na}^{+}$ & TAS [5] \\
\hline MIGS-22 & Oxygen requirement & Aerobe & TAS [5] \\
\hline MIGS-15 & Biotic relationship & Free-living & NAS \\
\hline MIGS-14 & Pathogenicity & Non-pathogenic & NAS \\
\hline MIGS-4 & Geographic location & Kenya & TAS [5] \\
\hline MIGS-5 & Sample collection & 1999 & TAS [5] \\
\hline MIGS-4.1 & Latitude & Not reported & \\
\hline MIGS-4.2 & Longitude & Not reported & \\
\hline MIGS-4.4 & Altitude & Not reported & \\
\hline
\end{tabular}

${ }^{a}$ Evidence codes - IDA: Inferred from Direct Assay; TAS: Traceable Author Statement (i.e., a direct report exists in the literature); NAS: Non-traceable Author Statement (i.e., not directly observed for the living, isolated sample, but based on a generally accepted property for the species, or anecdotal evidence). These evidence codes are from the Gene Ontology project [20]

\section{Genome sequencing information}

\section{Genome project history}

Thioalkalivibrio thiocyanoxidans $\mathrm{ARh} 2^{\mathrm{T}}$ was sequenced as part of a project aimed at sequencing a large number of Thioalkalivibrio isolates. The goal of this project is to enable the study of the genomic diversity of the dominant genus of sulfur-oxidizing bacteria in soda lakes. $T$. thiocyanoxidans ARh $2^{\mathrm{T}}$ was selected for its ability to grow in salt-saturated brines $\left(4.3 \mathrm{M} \mathrm{Na}^{+}\right)$and for its ability to grow on thiocyanate as the sole energy, sulfur and nitrogen source. The permanent draft genome we present here consists of approximately 2.8 million basepairs divided over 61 scaffolds. Sequencing was performed at the Joint Genome Institute under project 1008667. The

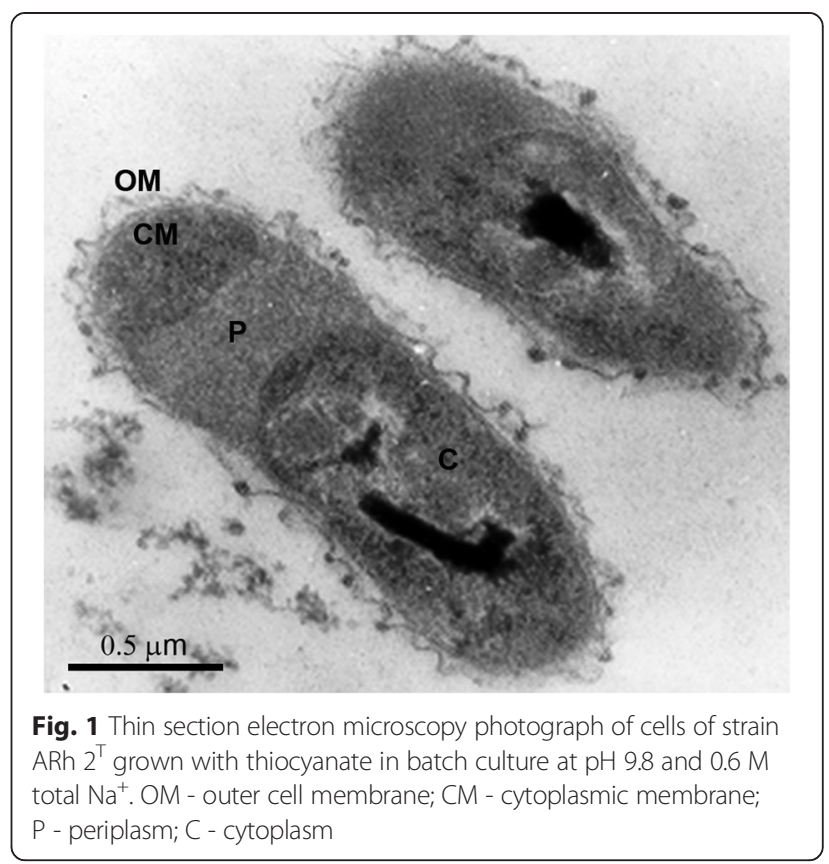

genome sequence was released in Genbank on December 25, 2014. An overview of the project is given in Table 2.

\section{Growth conditions and genomic DNA extraction}

T. thiocyanoxidans ARh $2^{\mathrm{T}}$ (DSM 13532) was cultured in a standard buffer containing sodium carbonate and bicarbonate at $\mathrm{pH} 10$. The total salt concentration was $0.6 \mathrm{M} \mathrm{Na}^{+}$[6]. The energy source was thiosulfate, at a concentration of $40 \mathrm{mM}$. After harvesting, the cells were stored at $-80{ }^{\circ} \mathrm{C}$ for further processing. Genomic DNA was extracted using a chloroform-phenol-isoamylalcohol mixture and precipitated with ethanol. After vacuum drying, the pellet was dissolved in water and the quantity and quality of the DNA determined using the JGIprovided Mass Standard Kit.

\section{Genome sequencing and assembly}

This strain was sequenced as part of the Community Science Program of the US Department of Energy Joint Genome Institute. The Illumina HiSeq 2000 platform was used for sequencing, with a depth of 1819X. More details regarding the library construction and sequencing are available at the JGI website. Reads were filtered using DUK and assembled using Velvet 1.1.04 [7]. Pseudoreads $(1-3 \mathrm{~Kb})$ were generated from the Velvet output using wgsim and reassembled using ALLPATHS-LG r42328 [8]. The final assembly consists of 61 scaffolds.

\section{Genome annotation}

Genes were predicted using Prodigal [9], followed by a round of manual curation using GenePRIMP [10] to detect pseudogenes. The resulting predicted genes were 


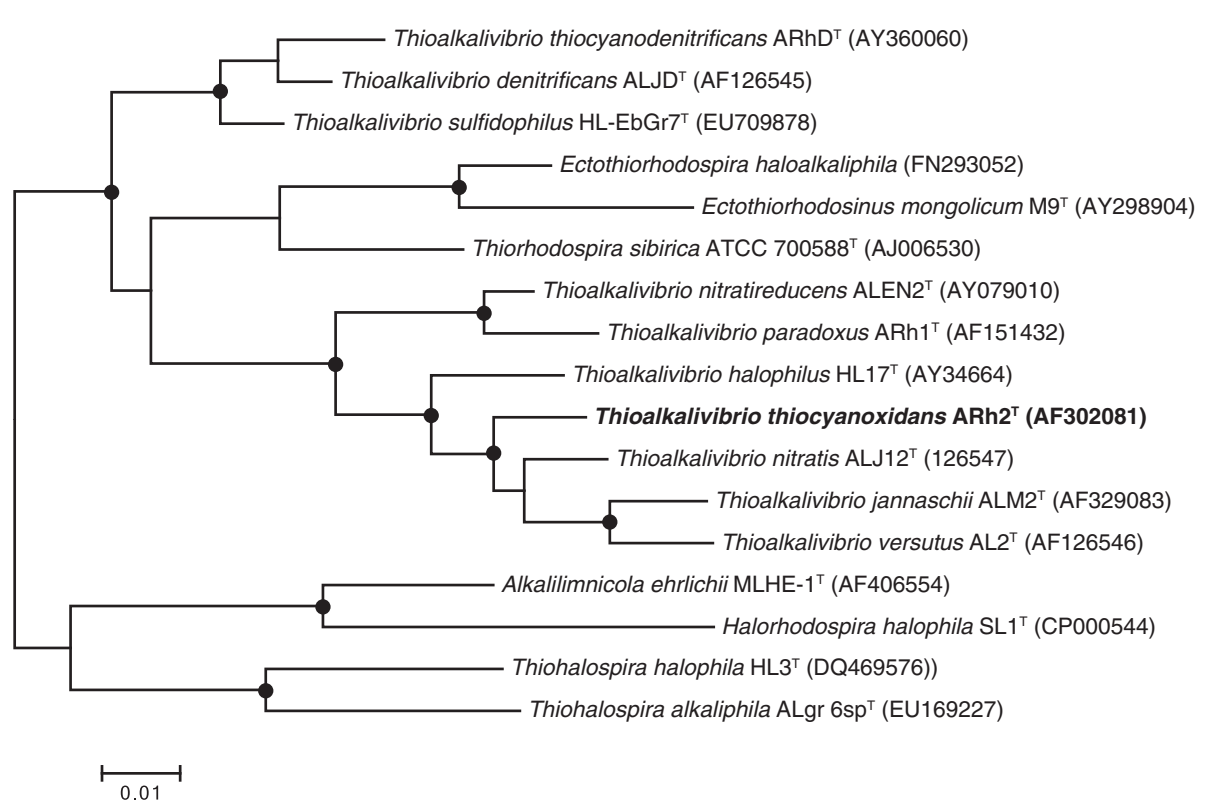

Fig. 2 Phylogenetic tree based on 165 rRNA sequences comprising the Thioalkalivibrio type strains and several other members of the Ectothiorhodospiraceae family. Black dots mark nodes with a bootstrap value between 90 and $100 \% .165$ rRNA sequences of members of the Alphaproteobacteria were used as the outgroup, but pruned from the tree. The tree was constructed using ARB [21] and bootstrap values calculated using MEGA6 [22]

translated and annotated using the NCBI NR database in combination with the UniProt, TIGRFam, Pfam, KEGG, COG and InterPro databases and tRNAScanSE [11] for tRNA prediction. Ribosomal RNAs were detected using models built from SILVA. Further annotation was performed using the Integrated Microbial Genomes platform. All annotation data is freely available there, with IMG submission ID 12214.

Table 2 Project information

\begin{tabular}{|c|c|c|}
\hline MIGS ID & Property & Term \\
\hline MIGS 31 & Finishing quality & Improved high-quality draft \\
\hline MIGS-28 & Libraries used & $\begin{array}{l}\text { Illumina standard fragment, } \\
270 \mathrm{bp}\end{array}$ \\
\hline MIGS 29 & Sequencing platforms & Illumina HiSeq 2000 \\
\hline MIGS 31.2 & Fold coverage & 1819 \\
\hline MIGS 30 & Assemblers & $\begin{array}{l}\text { Velvet 1.1.04 [7], ALLPATHS } \\
\text { R39750 [8] }\end{array}$ \\
\hline \multirow[t]{7}{*}{ MIGS 32} & Gene calling method & Prodigal [9], GenePRIMP [10] \\
\hline & Locus Tag & G372 \\
\hline & Genbank ID & ARQK00000000 \\
\hline & GenBank Date of Release & $2014-12-25$ \\
\hline & GOLD ID & Gp0025980 \\
\hline & BIOPROJECT & PRJNA185302 \\
\hline & IMG submission ID & 12214 \\
\hline \multirow[t]{2}{*}{ MIGS 13} & Source Material Identifier & DSM 13532 \\
\hline & Project relevance & Biotechnology \\
\hline
\end{tabular}

\section{Genome properties}

The final draft of the genome comprises 2.8 million base pairs in 61 scaffolds, with a $\mathrm{G}+\mathrm{C}$ percentage of $66.18 \%$. The gene calling and annotation pipeline detected 2677 genes, of which 2616 code for proteins. Basic statistics concerning the genome sequence are shown in Table 3. In total, $70 \%$ of the genes could be assigned functional categories based on COGs (see Table 4).

Table 3 Genome statistics

\begin{tabular}{lll}
\hline Attribute & Value & \% of Total \\
\hline Genome size (bp) & $2,765,337$ & 100.00 \\
DNA coding (bp) & $2,496,809$ & 90.29 \\
DNA G + C (bp) & $1,829,984$ & 66.18 \\
DNA scaffolds & 61 & 100.00 \\
Total genes & 2677 & 100.00 \\
Protein coding genes & 2616 & 97.72 \\
RNA genes & 61 & 2.28 \\
Pseudo genes & Not determined & Not determined \\
Genes in internal clusters & Not determined & Not determined \\
Genes with function prediction & 2230 & 83.30 \\
Genes assigned to COGs & 1885 & 70.41 \\
Genes with Pfam domains & 1799 & 78.94 \\
Genes with signal peptides & 217 & 8.11 \\
Genes with transmembrane helices & 655 & 24.47 \\
CRISPR repeats & 1 & 100.00 \\
\hline
\end{tabular}


Table 4 Number of genes associated with the 25 general COG functional categories

\begin{tabular}{|c|c|c|c|}
\hline Code & Value & $\%$ age & Description \\
\hline J & 148 & 7.09 & $\begin{array}{l}\text { Translation, ribosomal structure } \\
\text { and biogenesis }\end{array}$ \\
\hline A & 1 & 0.05 & RNA processing and modification \\
\hline K & 70 & 3.36 & Transcription \\
\hline $\mathrm{L}$ & 98 & 4.70 & Replication, recombination and repair \\
\hline B & 2 & 0.10 & Chromatin structure and dynamics \\
\hline D & 32 & 1.53 & $\begin{array}{l}\text { Cell cycle control, Cell division, } \\
\text { chromosome partitioning }\end{array}$ \\
\hline V & 29 & 1.39 & Defense mechanisms \\
\hline $\mathrm{T}$ & 105 & 5.03 & Signal transduction mechanisms \\
\hline M & 153 & 7.33 & Cell wall/membrane biogenesis \\
\hline N & 73 & 3.50 & Cell motility \\
\hline U & 72 & 3.45 & Intracellular trafficking and secretion \\
\hline O & 109 & 5.23 & $\begin{array}{l}\text { Posttranslational modification, protein } \\
\text { turnover, chaperones }\end{array}$ \\
\hline C & 148 & 7.09 & Energy production and conversion \\
\hline G & 82 & 3.93 & Carbohydrate transport and metabolism \\
\hline $\mathrm{E}$ & 145 & 6.95 & Amino acid transport and metabolism \\
\hline F & 60 & 2.88 & Nucleotide transport and metabolism \\
\hline H & 131 & 6.28 & Coenzyme transport and metabolism \\
\hline | & 86 & 3.02 & Lipid transport and metabolism \\
\hline$P$ & 105 & 5.03 & Inorganic ion transport and metabolism \\
\hline Q & 37 & 1.77 & $\begin{array}{l}\text { Secondary metabolites biosynthesis, } \\
\text { transport and catabolism }\end{array}$ \\
\hline $\mathrm{R}$ & 228 & 10.93 & General function prediction only \\
\hline$S$ & 195 & 9.35 & Function unknown \\
\hline - & 792 & 29.59 & Not in COGs \\
\hline
\end{tabular}

The total is based on the total number of protein coding genes in the genome

\section{Conclusions}

Sequencing of the genome of Thioalkalivibrio thiocyanoxidans ARh $2^{\mathrm{T}}$ is an important step towards a more comprehensive understanding of the mechanism by which this organism can adapt to extremely high salinity. In addition, it will provide important information on the role of this organism in the carbon and sulfur cycles of natural and engineered environments, in particular in the degradation of thiocyanate.

\section{Competing interests}

The authors declare that they have no competing interests.

\section{Authors' contributions}

TB is responsible for drafting the manuscript and - together with GM and DS - for discussion and revisions. DS grew the organism and extracted the DNA. Sequencing and annotation were performed by NI, AP, NK, LAG and TW. All authors approve of the final version.

\section{Acknowledgements}

The work conducted by the U.S. Department of Energy Joint Genome Institute, a DOE Office of Science User Facility, is supported under Contract No.
DE-AC02-05CH11231. Tom Berben and Gerard Muyzer are supported by ERC Advanced Grant PARASOL (No. 322551). Dimitry Sorokin is supported by RBFR Grant 13-04-00049.

\section{Author details}

${ }^{1}$ Microbial Systems Ecology, Institute of Biodiversity and Ecosystem Dynamics, University of Amsterdam, Amsterdam, The Netherlands. ${ }^{2}$ Winogradsky Institute of Microbiology, RAS, Moscow, Russia. ${ }^{3}$ Department of Biotechnology, Delft University of Technology, Delft, The Netherlands. ${ }^{4}$ Joint Genome Institute, Walnut Creek, CA, USA.

Received: 27 March 2015 Accepted: 13 October 2015

Published online: 26 October 2015

\section{References}

1. Grant WD. Alkaline environments and biodiversity. In: Gerday C, Glansdorff N, editors. Extremophiles; Encyclopedia of Life Support Systems (EOLSS). Oxford: EOLSS publishers; 2006.

2. Sorokin DY, Kuenen JG, Muyzer G. The microbial sulfur cycle in soda lakes. Frontiers in Microbial Physiology. 2011;2:article 44.

3. Sorokin DY, Berben T, Melton ED, Overmars L, Vavourakis CD, Muyzer G. Microbial diversity and biogeochemical cycling in soda lakes. Extremophiles. 2014;18:791-809.

4. Sorokin DY, van den Bosch PLF, Abbas B, Janssen AJH, Muyzer G. Microbiological analysis of the population of extremely haloalkaliphilic sulfur-oxidizing bacteria dominating in lab-scale sulfide-removing bioreactors. Appl Microbiol Biotechnol. 2008;80:965-75.

5. Sorokin DY, Tourova TP, Lysenko AM, Mityushina LL, Kuenen JG. Thioalkalivibrio thiocyanoxidans sp. nov. and Thioalkalivibrio paradoxus sp. nov., novel alkaliphilic, obligately autotrophic, sulfuroxidizing bacteria capable of growth on thiocyanate, from soda lakes. Int J Syst Evol Microbiol. 2002;52:657-64.

6. Sorokin DY, Banciu H, Robertson LA, Kuenen JG. Haloalkaliphilic sulfur-oxidizing bacteria. In: Dworkin M, Falkow S, Rosenberg E, Schleifer KH, Stackebrandt E, editors. The Prokaryotes. Volume 2. 3rd ed. New York: Springer; 2006. p. 969-84.

7. Zerbino DR, Birney E. Velvet: algorithms for de novo short read assembly using de Bruijn graphs. Genome Res. 2008;18:821-9.

8. Gnerre S, MacCallum I, Przybylski D, Ribeiro F, Burton J, Walker B, et al. High-quality draft assemblies of mammalian genomes from massively parallel sequence data. Proc Natl Acad Sci. 2011;108:1513-8.

9. Hyatt D, Chen G, LoCascio PF, Land ML, Larimer FW, Hauser LJ. Prodigal: prokaryotic gene recognition and translation initiation site identification. BMC Bioinformatics. 2010;11:119.

10. Pati A, Ivanova NN, Mikhailova N, Ovchinnikova G, Hooper SD, Lykidis A, et al. GenePRIMP: a gene prediction improvement pipeline for prokaryotic genomes. Nat Methods. 2010;7:455-7.

11. Lowe TM, Eddy SR. tRNAscan-SE. A program for improved detection of transfer RNA genes in genomic sequence. Nucl Acids Res. 1997;25:955-64.

12. Field D, Garrity G, Gray T, Morrison N, Selengut J, Sterk P, et al. The Minimum Information about a Genome Sequence (MIGS) specification. Nat Biotechnol. 2008;26:541-7.

13. Woese CR, Kandler O, Wheelis ML. Towards a natural system of organisms: proposal for the domains Archaea, Bacteria, and Eucarya. Proc Natl Acad Sci USA. 1990;87:4576-9.

14. Garrity GM, Bell JA, Lilburn T. Phylum XIV. Proteobacteria phyl. nov. In: Garrity GM, Brenner DJ, Krieg NR, Staley JT, editors. Bergey's Manual of Systematic Bacteriology, Volume 2, Part B. 2nd ed. New York: Springer; 2005. p. 1.

15. Validation of publication of new names and new combinations previously effectively published outside the IJSEM. Int J Syst Evol Microbiol. 2005; 55:2235-38.

16. Garrity GM, Bell JA, Lilburn T. Class III. Gammaproteobacteria class. nov. In: Garrity GM, Brenner DJ, Krieg NR, Staley JT, editors. Bergey's Manual of Systematic Bacteriology, Volume 2, Part B. 2nd ed. New York: Springer; 2005. p. 1.

17. Garrity GM, Bell JA, Lilburn T. Order I. Chromatiales ord. nov. In: Garrity GM, Brenner DJ, Krieg NR, Staley JT, editors. Bergey's Manual of Systematic Bacteriology, Volume 2, Part B. 2nd ed. New York: Springer; 2005. p. 1.

18. Imhoff JF. Reassignment of the genus Ectothiorhodospira Pelsh 1936 to a new family, Ectothiorhodospiraceae fam. nov., and emended description of the Chromatiaceae Bavendamm 1924. Int J Syst Evol Microbiol. 1984;34:338-9. 
19. Sorokin DY, Lysenko AM, Mityushina LL, Tourova TP, Jones BE, Rainey FA, et al. Thioalkalimicrobium aerophilum gen. nov., sp. nov. and

Thioalkalimicrobium sibericum sp. nov., and Thioalkalivibrio versutus gen. nov. sp. nov., Thioalkalivibrio nitratis sp. nov. and Thioalkalivibrio denitrificans sp. nov., novel obligately alkaliphilic and obligately chemolithoautotrophic sulfur-oxidizing bacteria from soda lakes. Int J Syst Evol Microbiol. 2001;51:565-80.

20. Ashburner M, Ball CA, Blake JA, Botstein D, Butler H, Cherry JM, et al. Gene Ontology: tool for the unification of biology. Nat Genet. 2000;25:25-9.

21. Ludwig W, Strunk O, Westram R, Richter L, Meier H, Yadhukumar, et al. ARB: a software environment for sequence data. Nucl Acids Res. 2004;32:1363-71.

22. Tamura K, Stecher G, Peterson D, Filipski A, Kumar S. MEGA6: Molecular Evolutionary Genetics Analysis Version 6.0. Mol Biol Evol. 2013;30:2725-9.

\section{Submit your next manuscript to BioMed Central and take full advantage of:}

- Convenient online submission

- Thorough peer review

- No space constraints or color figure charges

- Immediate publication on acceptance

- Inclusion in PubMed, CAS, Scopus and Google Scholar

- Research which is freely available for redistribution 